\title{
STEFFENSEN'S INEQUALITY FOR POSITIVE MEASURES
}

\author{
JULIJE JAKŠETIĆ AND JOSIP PEČARIĆ
}

Abstract. We generalize Steffensen's inequality for positive measures. We obtain conditions for these inequalities which are invariant in form to Steffensen's inequality for absolutely continuous measures. Further, we produce linear functionals which generate exponential convexity and Cauchy means.

Mathematics subject classification (2010): 26D15, 26D20.

Keywords and phrases: Steffensen's inequality, measure theory, divided difference, exponential convexity.

\section{REFERENCES}

[1] N. I. AkHIEZER, The Classical Moment Problem and Some Related Questions in Analysis, Oliver and Boyd, Edinburgh, 1965.

[2] S. N. Bernstein, Sur les fonctions absolument monotones, Acta Math. 52 (1929), 1-66.

[3] J. C. Evard, H. Gauchman, Steffensen type inequalites over general measure spaces, Analysis 17, 2-3 (1997), 301-322.

[4] H. Gauchman, A Steffensen type inequality, J. Inequal. Pure Appl. Math. 1, 1 (2000), Article 3.

[5] H. Gauchman, On further generalization of Steffensen's inequality, J. Inequal. Appl. 5, 5 (2000), 505-513.

[6] J. JAKŠEtić, J. PEČARIĆ, Exponential convexity method, J. Convex Anal. 20, 1 (2013), 181-197.

[7] J. PEČARIĆ, J. PERIĆ, Improvements of the Giaccardi and the Petrović inequality and related results, An. Univ. Craiova Ser. Mat. Inform., 39, 1 (2012), 65-75.

[8] J. E. Pečarić, F. Proschan, Y. L. Tong, Convex functions, partial orderings, and statistical applications, Mathematics in science and engineering 187, Academic Press, 1992.

[9] J. PeČarić, K. Smoljak Kalamir, S. Varoš Anec, Steffensen's and Related Inequalities, A Comprehensive Survey and Recent Advances, Monographs in inequalities 7, Element, 2014.

[10] J. L. SCHIFF, The Laplace transform. Theory and applications, Undergraduate Texts in Mathematics, Springer-Verlag, New York, 1999.

[11] J. F. STEFFENSEN, On certain inequalities between mean values and their application to actuarial problems, Skand. Aktuarietids. (1918), 82-97. 